\title{
Hubungan Konsumsi Alkohol dengan Kadar High Density Lipoprotein
}

\author{
${ }^{1}$ Aditya N. Batara \\ ${ }^{2}$ Erwin Pangkahila \\ ${ }^{2}$ Hedison Polii
}

\author{
${ }^{1}$ Program Studi Pendidikan Dokter Fakultas Kedokteran Universitas Sam Ratulangi Manado \\ ${ }^{2}$ Bagian Fisiologi Fakultas Kedokteran Universitas Sam Ratulangi Manado \\ Email:yanovianto04@gmail.com
}

\begin{abstract}
Alcohol consumption has some effect on myocardial infarction (heart attack), and could decrease low density lipoprotein (LDL) level as well as increase high density lipoprotein (HDL) level. This study was aimed to determine the relationship between alcohol consumption and HDL level. This was an analytical study with a cross sectional design. Subjects were students of Faculty of Social and Political Sciences at Sam Ratulangi University. Data were analyzed by using the Spearman correlation test (significancy $<0.05$ ). The results showed that 31 students were involved in this study. There were 26 students (83.87\%) with normal HDL levels and 5 students (16.13\%) with abnormal HDL levels. The Spearman test of the correlation between alcohol consumption (frequency, duration, and the amount of alcohol consumption) and HDL level showed the $P$ values, as follows: $P=0.256$, $P=0.410$, and $P=0.459$. Conclusion: There was no correlation between alcohol consumption and HDL level.
\end{abstract}

Keywords: alcohol, HDL levels

\begin{abstract}
Abstrak: Konsumsi alkohol diketahui memiliki efek terhadap infark miokard, penurunan kadar low density lipoprotein (LDL), dan peningkatan kadar high density lipoprotein (HDL). Penelitian ini bertujuan untuk mengetahui hubungan konsumsi alkohol dengan kadar HDL. Jenis penelitian ialah analitik dengan desain potong lintang. Subyek penelitian ialah mahasiswa Fakultas Ilmu Sosial dan Politik di Universitas Sam Ratulangi. Analisis data menggunakan uji korelasi Spearman dengan nilai signifikansi $P \leq 0,05$. Hasil penelitian mendapatkan 31 mahasiswa laki-laki sebagai subyek penelitian. Subyek yang memiliki kadar HDL normal sebanyak 26 orang $(83,87 \%)$ dan yang tidak normal sebanyak 5 orang $(16,13 \%)$. Uji korelasi Spearman terhadap hubungan antara konsumsi alkohol (frekuensi konsumsi, lama konsumsi, jumlah konsumsi alkohol) dengan kadar HDL memiliki nilai $P$ berturut-turut ialah $P=0,256, P=0,410$, dan $P=0,459$. Simpulan: Tidak terdapat hubungan bermakna antara konsumsi alkohol dengan kadar HDL.
\end{abstract}

Kata kunci: alkohol, kadar HDL

Sejak dahulu manusia telah mengonsumsi berbagai zat dengan maksud akan mengurangi rasa nyeri atau mengubah tingkat kesadaran. Manusia telah menemukan semacam zat beracun yang memengaruhi sistem saraf pusat (SSP), menghilangkan penderitaan fisik dan mental, serta menghasilkan euphoria. Salah satu zat yang sering disalahgunakan yakni alkohol. ${ }^{1}$
Kolesterol sangat larut dalam lemak tetapi hanya sedikit larut dalam air, dan mampu membentuk ester dengan asam lemak. Sebenarnya, hampir $70 \%$ kolesterol dalam lipoprotein plasma berada dalam bentuk ester kolesterol. Disamping kolesterol diabsorbsi setiap hari dari saluran cerna yang disebut kolesterol eksogen, suatu jumlah yang bahkan lebih besar 
dibentuk dalam sel-sel tubuh disebut kolesterol endogen. Pada dasarnya semua kolesterol endogen yang beredar dalam lipoprotein plasma dibentuk oleh hati, tetapi semua sel tubuh lain setidaknya membentuk sedikit kolesterol, yang sesuai dengan kenyataan bahwa banyak struktur membran dari seluruh sel sebagian disusun dari zat ini. ${ }^{2}$

High density lipoprotein (HDL) adalah bentuk lipoprotein (lipid dan protein) dengan densitas lipoprotein tinggi yang dibentuk di usus dan hati. HDL seringkali dijuluki sebagai kolesterol baik. Apolipoprotein pada HDL adalah Apo A1 dan Apo A2. ${ }^{3}$

Berdasarkan data dari Riset Kesehatan Dasar (RISKESDAS) 2007, ${ }^{4}$ prevalensi nasional minum alkohol selama 12 bulan terakhir ialah $4,6 \%$. Sebanyak 15 provinsi mempunyai prevalensi minum alkohol selama 12 bulan terakhir diatas prevalensi nasional, yaitu Sumatera Utara, Kepulauan Riau, Bali, Nusa Tenggara Timur, Kalimantan Barat, Kalimantan Tengah, Sulawesi Utara, Sulawesi Tengah, Sulawesi Selatan, Sulawesi Tenggara, Gorontalo, Maluku, Maluku Utara, Papua Barat, dan Papua. Beberapa provinsi memiliki prevalensi minum alkohol tertinggi, yaitu provinsi Nusa Tenggara Timur $(17,7 \%)$, Sulawesi Utara $(17,4 \%)$, dan Gorontalo $(12,3 \%)$. Di Sulawesi Utara prevalensi minum alkohol tertinggi yaitu di Kota Tomohon (36\%) dan terendah di Kabupaten Bolaang Mongondow $(5,5 \%){ }^{5}$

Konsumsi alkohol diketahui berefek terhadap infark miokard, penurunan kadar low density lipoprotein (LDL) dan fibrinogen, serta peningkatan kadar HDL. Pada konsumsi alkohol sering didapatkan peningkatan HDL yaitu suatu penanda kolesterol sehat. $^{5}$

Berdasarkan uraian di atas, konsumsi alkohol merupakan salah satu faktor yang memengaruhi kadar HDL. Penelitian ini bertujuan untuk mengetahui hubungan konsumsi alkohol dengan kadar HDL.

\section{METODE PENELITIAN}

Jenis penelitian yang digunakan ialah analitik dengan desain potong lintang. Penelitian dilakukan di Fakultas Ilmu Sosial dan Politik (FISIP) Jurusan Ilmu Pemerintahan Universitas Sam Ratulangi Manado. Populasi ialah maha-siswa FISIP. Pengambilan sampel dilakukan dengan metode purposive sampling yang memenuhi kriteria, yaitu mahasiswa berjenis kelamin laki-laki berusia 18-25 tahun, mengonsumsi alkohol minimal 1 kali dalam seminggu, dan bersedia menjadi subjek penelitian dengan mengisi informed consent.

Instrumen dan bahan penelitian yang dipakai ialah jarum suntik, toruniquet, alkohol, kapas, sampel darah, dan reagen untuk pemeriksaan kadar kolesterol HDL. Sampel darah diambil melalui pembu-luh darah vena pada lipat siku (fossa cubiti). Setelah itu sampel darah tersebut di masukkan kedalam tabung sampel darah untuk diperiksa kadar HDL dalam darah di Laboratorium Prokita Manado.

\section{HASIL PENELITIAN}

Pada penelitian ini didapatkan 31 orang mahasiswa laki-laki sebagai subyek penelitian. Tabel 1 memperlihatkan bahwa distribusi frekuensi konsumsi alkohol 1-2 kali per minggu berjumlah 10 subyek (32,3\%), untuk frekuensi konsumsi alkohol 3-4 kali per minggu berjumlah 18 subyek $(58,1 \%)$ dan untuk frekuensi konsumsi alkohol 5-6 kali per minggu berjumlah 3 subyek $(9,7 \%)$.

Tabel 1. Karakteristik berdasarkan frekuensi konsumsi alkohol

\begin{tabular}{ccc}
\hline $\begin{array}{c}\text { Frekuensi } \\
\text { konsumsi } \\
\text { (kali/minggu) }\end{array}$ & (n) & $\begin{array}{c}\text { Persentase } \\
(\%)\end{array}$ \\
\hline $1-2$ & 10 & 32,3 \\
$3-4$ & 18 & 58,1 \\
$5-6$ & 3 & 9,7 \\
Total & 31 & 100 \\
\hline
\end{tabular}

Tabel 2 memperlihatkan distribusi subyek berdasarkan jumlah yang dikonsumsi dalam seminggu. Didapatkan bahwa subyek yang mengonsumsi 4-6 sloki 
berjumlah 5 orang $(16,1 \%)$; yang mengonsumsi $7-9$ sloki berjumlah 4 orang $(12,9 \%)$ dan yang mengonsumsi $>10$ sloki berjumlah 22 orang $(71 \%)$.

Tabel 2. Karakteristik berdasarkan jumlah konsumsi alkohol

\begin{tabular}{ccc}
\hline $\begin{array}{c}\text { Jumlah konsumsi } \\
\text { alkohol (Sloki) }\end{array}$ & (n) & $\begin{array}{c}\text { Persentase } \\
(\boldsymbol{\%})\end{array}$ \\
\hline $4-6$ & 5 & 16,1 \\
$7-9$ & 4 & 12,9 \\
$>10$ & 22 & 71 \\
Total & 31 & 100 \\
\hline
\end{tabular}

Tabel 3 menampilkan distribusi subyek berdasarkan lama mengonsumsi alkohol, yaitu 1-5 tahun berjumlah 14 orang $(45,2 \%)$ dan 6-10 tahun berjumlah 17 orang $(54,8 \%)$.

Tabel 3. Karakteristik berdasarkan lamanya konsumsi alkohol

\begin{tabular}{ccc}
\hline $\begin{array}{c}\text { Lama konsumsi } \\
\text { alkohol (tahun) }\end{array}$ & (n) & $\begin{array}{c}\text { Persentase } \\
(\%)\end{array}$ \\
\hline $1-5$ & 14 & 45,2 \\
$6-10$ & 17 & 54,8 \\
Total & 31 & 100 \\
\hline
\end{tabular}

Tabel 4 menunjukkan bahwa kadar HDL normal terdapat pada 26 subyek $(83,9 \%)$ dan kadar HDL rendah sebanyak 5 subyek $(16,1 \%)$

Tabel 4. Karakteristik responden berdasarkan kadar HDL

\begin{tabular}{cccc}
\hline $\begin{array}{c}\text { Klasifikasi } \\
\text { kadar HDL }\end{array}$ & $\begin{array}{c}\text { Nilai } \\
\text { rujukan } \\
(\mathbf{m g} / \mathbf{d L})\end{array}$ & $\begin{array}{c}\text { (n) } \\
\text { Norsentase } \\
(\boldsymbol{\%})\end{array}$ \\
\hline Rermal & $>40$ & 26 & 83,9 \\
\hline
\end{tabular}

\section{BAHASAN}

Jenis penelitian yang dilakukan ialah analitik observasional dengan desain potong lintang yang bertujuan untuk mengetahui apakah terdapat hubungan mengonsumsi alkohol dengan kadar HDL yang dilakukan terhadap 31 subyek laki-laki yaitu mahasiswa Fakultas Ilmu Sosial dan Politik jurusan Ilmu Pemerintahan yang memenuhi kriteria inklusi dan ekslusi.

Pada pemeriksaan kadar HDL dengan karakteristik frekuensi konsumsi, lamanya konsumsi, dan jumlah konsumsi ialah $P=0,256, \quad P=0,410, \quad$ dan $P=0,459$ yang menunjukkan tidak terdapat hubungan antara konsumsi alkohol dengan kadar HDL.

Berdasarkan hasil penelitian ini didapatkan frekuensi mengonsumsi alkohol terbanyak 3-4 kali per minggu dan jumlah yang dikonsumsi terbanyak $>10$ sloki. Subyek dengan kadar HDL normal yaitu sebanyak 26 orang dan yang dengan kadar HDL rendah sebanyak 5 orang. Hasil penelitian ini selaras dnegan penelitian oleh Gordon et $\mathrm{al}^{6}$ yang menyatakan sebagian besar subyek yang mengonsumsi allohol memiliki kadar HDL yang lebih tinggi.

Studi epidemiologi yang dilakukan oleh Hulley dan Gordon ${ }^{7}$ mendapatkan rerata kadar HDL yang tinggi pada responden yang mengonsumsi alkohol. Terdapat faktor lain yang memengaruhi kadar HDL seseorang, yaitu merokok dan berat badan. Pada percobaan yang dilakukan terjadi penurunan kadar HDL sebanyak $15 \%$ pada responden yang tidak mengonsumsi alkohol selama dua minggu.

Pada penelitian yang dilakukan oleh Zaid et $\mathrm{al}^{8}$ didapatkan hasil kadar HDL pada responden yang mengonsumsi alkohol lebih tinggi daripada kadar HDL responden yang tidak mengonsumsi alkohol. Asupan alkohol telah disarankan untuk memengaruhi HDL dengan meningkatkan aktivitas lipase dan menurunkan cholesteryl ester transfer protein (CETP).

\section{SIMPULAN}

Berdasarkan hasil penelitian ini dapat disimpulkan bahwa tidak terdapat hubungan bermakna antara konsumsi alkohol dengan kadar HDL pada mahasiswa Fakultas Ilmu Sosial dan Politik Jurusan Ilmu Pemerintahan.

\section{SARAN}

Perlu dilakukan penelitian lebih lanjut mengenai hubungan konsumsi alkohol dan kadar HDL dengan jumlah sampel yang 
lebih besar. Perlu diteliti faktor kebiasaan hidup seperti merokok, riwayat aktivitas fisik, asupan gizi, dan IMT

Ucapan terima kasih ditujukan kepada seluruh mahasiswa Jurusan Ilmu Pemerintahan Fakultas Ilmu Sosial dan Politik Universitas Sam Ratulangi Manado atas partisipasinya dalam penelitian ini, Laboratorium Klinik Patra atas bantuan dan kerja samanya, serta pihak lain yang terlibat dalam penyelesaian penelitian ini.

\section{DAFTAR PUSTAKA}

1. Davidson GC, Neal JM, Kring AM. Gangguan yang berkaitan dengan pengunaan zat. Psikologi Abnormal (9th ed). Depok: Raya Grafindo Persada, 2012.

2. Sanhia AM, Pangemanan DHC, Engka JN. Gambaran kadar low density lipoprotein (LDL) pada masyarakat perokok di pesisir pantai. eBm. 2015;3(1):460-5.

3. Ginting M, Mustari, Nasution N, Harahap H. Karakteristik pasien rawat jalan usia 40-65 tahun yang melakukan pemeriksaan HDL Kolesterol di RSUP H. Adam Malik Medan (Tesis). Medan: Politeknik Kesehatan Depkes Medan.
4. Riset Kesehatan Dasar. 2007. Jakarta: Badan Penelitian dan Pengembangan Kesehatan Departemen Kesehatan Republik Indonesia. [cited 2018 Aug 31]. Available from: http://staff.ui.ac.id/ system/files/ users/kuntarti/material/riskesdalaporanna sional.pdf

5. Putra A. Pengaruh alkohol terhadap kesehatan. [cited 2018 Aug 31]. Available from: https://ejournal.undiksha. ac.id/index.php/semnasmipa/article/view File/2749/2327

6. Gordon T, Ernst N, Fisher M, dan Rifkind BM. Alcohol and high-density lipoprotein cholesterol. [cited 2018 Nov 22]. Available from:https://www.ncbi. nlm.nih.gov/pubmed/7020986.1

7. Hulley SB, Gordon S. Alcohol and highdensity lipoprotein cholesterol: causal inference from diverse study designs. 1981. [cited 2018 Nov 28]. Available from: https://europepmc.org/abstract/ med/7020985.

8. Zaid M, Miura K, Okayama A, Nakagawa H, Sakata K, Saitoh $S$, et al. Associations of high-density lipoprotein particle and high-density lipoprotein cholesterol with alcohol intake, smoking, and body mass index - the INTERLIPID study. Circ J. 2018;82(10):2557-65. 